\title{
The role of mycorrhizas in forest soil stability with climate change
}

\author{
Simard1, Suzanne W., and Austin², Mary E. \\ ${ }^{1}$ University of British Columbia, Vancouver, Canada, and ${ }^{2}$ Corvallis, USA
}

\section{Introduction}

Global change and the related loss of biodiversity as a result of explosive human population growth and consumption are the most important issues of our time. Global change, including climate change, nitrogen deposition, land-use change and species invasions, are altering the function, structure and stability of the Earth's ecosystems (Vitousek, 1994; Lovelock, 2009). Climate change specifically has been marked by an $80 \%$ increase in atmospheric $\mathrm{CO}_{2}$ levels and a $0.74{ }^{\circ} \mathrm{C}$ increase in average global near-surface temperature over the period 1906-2005, with average temperature projected to increase by an additional 1 to $6^{\circ} \mathrm{C}$ by 2100 (IPCC, 2007). Warming is expected to continue for centuries, even if greenhouse gas emission are stabilized, owing to time lags associated with climate processes and feedbacks (IPCC, 2007). Precipitation patterns have changed along with temperature, with average annual increases up to $20 \%$ in high-latitude regions but decreases up to $20 \%$ in mid- and low-latitudinal regions. The changes in temperature and precipitation patterns have resulted in higher sea levels, decreases in the extent of snow and ice, earlier timing of species spring events, upward and poleward shifts in species ranges, increases and earlier spring run-offs, and increases in forest disturbances by fires, insects and diseases. Of critical importance are the effects of global change on soils. Soils store one-third of the Earth's carbon and, therefore, small shifts in soil biogeochemistry could affect the global carbon balance (Schlesinger \& Andrews, 2004). The effects of global change on soils are complex, however, with multiple feedbacks across broad spatiotemporal scales that have the potential to further amplify climate change effects on the ecology of the Earth. Changes in soils are already occuring as a result of climate change, and include increased soil temperatures, increased nutrient availability, melting of permafrost, increased ground instability in mountainous regions, and increased erosion from floods (IPCC, 2007).

Forests are especially important in the carbon balance of the Earth. Even though forests comprise only $30 \%$ of the terrestrial ecosystems, they store $86 \%$ of the above-ground carbon and $73 \%$ of the world's soil carbon (Sedjo, 1993). On average, forests store two-thirds of their carbon in soils, where much of it is protected against turnover in soil aggregates or in chemical complexes (FAO, 2006). Forest soils not only absorb and store large quantities of carbon, they also release greenhouse gases such as $\mathrm{CO}_{2}, \mathrm{CH}_{4}$ and $\mathrm{N}_{2} \mathrm{O}$. The carbon sink and source strengths of soils have been considered relatively stable globally, with the strong sink strength of northern-mid latitudes roughly balanced by the strong source strength of the 
tropics (Houghton et al., 2000). However, climate change can upset the soil carbon balance, or its functional stability, by reducing carbon storage and causing a large positive feedback to atmospheric $\mathrm{CO}_{2}$ levels. Indeed, the amount of $\mathrm{CO}_{2}$ emissions being sequestered by terrestrial ecosystems is declining and they may become a source by the middle of the 21st century (Cox et al., 2000; Kurz et al., 2008a). When this happens, the atmospheric carbon trajectory will become less dependent on human activities and more so on the much larger carbon pools in terrestrial ecosystems and oceans (Cox et al., 2000). To underscore the gravity of this shift, the magnitude of total belowground respiration is already approximately 10 times greater than fossil fuel emissions annually (Lal, 2004). The effect of climate change on soil functional stability is particularly concerning in high latitude ecosystems (boreal forests, taiga, tundra and polar regions) because these systems store $30 \%$ of the Earth's carbon, and are currently warming at the fastest rates globally (IPCC, 2007; Schuur et al., 2009). The tundra-polar regions recently became a net source of atmospheric $\mathrm{CO}_{2}$ (Apps et al., 2005). The functional stability of soils or ecosystems is defined in this paper as the maintenance of soil or ecological complexity within certain bounds so that key processes (e.g., carbon cycling, productivity) are protected and maintained (Levin, 2005).

Although the climate change forecasts by the IPCC (2007) have the illusion of predictable and steady change over the next century, the real changes in climate will likely be sudden and unexpected (Lovelock, 2009). Indeed, non-linearity, unpredictability and disequilibrium characterize the Earth and its ecosystems as complex systems (Levin, 2005). Congruently, the IPCC (2007) is predicting an increase in the frequency of climatic extremes, such as heavy rains, heat waves and hot days/nights. These will affect disturbances caused by fire, drought, hurricanes, windstorms, icestorms, insect and disease outbreaks, and invasion by exotic species, and these are projected to increase in frequency, extent, severity and intensity as climate changes (Dale et al., 2001). Changes in natural disturbance regimes have the potential to increase the uncertainty in climate change projections because of their large effects on terrestrial carbon pools (Houghton et al., 2000; Kurz et al., 2008b). Disturbances could greatly overshadow the direct incremental effects of climate change on forest soil and ecosystem stabililty, or the effect of mitigation efforts (Kurz et al., 2008b). Large increases in forest fire and insect disturbances in Canada since 1980 have already reduced ecosystem carbon storage (Kurz \& Apps, 1999). Disturbances not only kill plants and affect soil carbon storage, but they also accelerate nutrient cycling, alter mycorrhizal communities, and change soil foodweb dynamics.

Carbon storage in soils involves complex feedbacks between plants and soil organisms. Carbon storage depends on the balance between carbon inputs through photosynthesis and outputs through autotrophic (root and mycorrhiza) and heterotrophic (soil microbial) respiration (Bardgett et al., 2008). Both photosynthesis and respiration are directly affected by climate change factors; including atmpospheric $\mathrm{CO}_{2}$ level, soil nutrient availability, and temperature and precipitation patterns. They are also clearly affected by tree mortality. The direct effects of these climate change factors on plants then feed back to indirectly affect the structure and activity of soil microbial communities, which drive nutrient cycling, soil carbon storage, and soil stability (Bever et al., 2002a). The intimate cascading interaction between plants and soil microbes in their response to climate change factors is likely of critical importance in predicting the consequences of climate change to ecosystem stability and the carbon balance. Although the feedbacks are complex and poorly understood, we are already measuring climate change effects on soil carbon in high latitude ecosystems (Apps 
et al., 2005; Schuur et al., 2009) as well as on the composition and activity of soil communities involved in soil nutrient cycling in northern forests (Treseder, 2008).

Of the soil microbes, mycorrhizal fungi are likely the most intimately involved and responsive to carbon fluxes between plants, soils and the atmosphere, and hence are important to consider in climate change impacts on terrestrial ecosystems. This is because of their pivotal position at the root-soil interface, where they link the aboveground and belowground components of biogeochemical cycles. Mycorrhizal fungi are obligate symbionts with all forest tree species, where they scavenge soil nutrients and water from the soil in exchange for photosynthate from the tree. Without their fungal symbionts, most trees cannot acquire enough soil resources to grow or reproduce; without the trees, the fungi have insufficient energy to carry out their life cycle. Because of this obligatory exchange, mycorrhizal fungi are considered the primary vectors for plant carbon to soils (Talbot et al., 2008) and, conversely, the primary vectors of soil nutrients to plants (Hobbie \& Hobbie, 2006). The fungal partner plays a role in other essential services as well, such as increasing soil structure, protecting soil carbon against mineralization, and protecting tree roots against disease or drought. A single mycorrhizal fungus can also link different plants together, thus forming mycorrhizal networks. These networks have been shown to facilitate regeneration of new seedlings, alter species interactions, and change the dynamics of plant communities (Selosse et al., 2006). As such, mycorrhizas are considered key players in the organization and stability of terrestrial ecosystems (Smith \& Read, 1997; Simard, 2009).

The objective of this synthesis paper is to review the role of mycorrhizas and mycorrhizal networks in the stability of forest ecosystems and forest soils as climate changes. We start by reviewing the role mycorrhizal fungi play in soil carbon flux dynamics. We then review some of the direct effects of climate change factors (specifically increased $\mathrm{CO}_{2}$, nutrient availability, temperature and drought) on plants and mycorrhizal fungi. Next, we briefly review the current and potential effects of climate change on forests in North America. The crux of our review, however, is on the role of mycorrhizas and mycorrhizal networks in helping to mitigate the effects of climate change through their stabilizing effects on forest ecosystems. We use our own research in the interior Douglas-fir forests of western North America to illustrate these stabilizing effects, including the role of mycorrhizal networks in forest recovery following disturbance and in soil carbon flux dynamics. We then discuss the potential roles that management can play in helping maintain forest stability as climate changes. The body of studies suggests that mycorrhizal fungi, and their capacity to stabilize forests, will have a significant impact on the terrestrial portion of the global carbon budget.

\section{The role of mycorrhizal fungi in soil carbon fluxes}

The soil carbon pool is 3.3 times larger than the atmospheric carbon pool and 4.5 times larger than the biological carbon pool (Lal, 2004). As a result, the global carbon balance is strongly influenced by soil carbon flux dynamics. The global soil carbon pool is $2500 \mathrm{Gt}$, and is comprised of $1500 \mathrm{Gt}$ organic carbon (70\%) and $950 \mathrm{Gt}$ inorganic carbon $(30 \%)$ (Schlesinger \& Andrews, 2004; Lal, 2004). The organic portion of the soil pool is comprised of plant roots, fungal biomass, microbial biomass, and decaying residues. It includes fastcycling sugars, amino acids and proteins, and slow-cycling cellulose, hemicellulose and lignin. The soil organic pool is highly dynamic, variable, and greatly influenced by land use practices (Rice et al., 2004). 
There are three functional groups of fungi in soils: mycorrhizal (i.e., mutalists), saprotrophic (i.e., decomposers) and pathogenic (i.e., parasitic) fungi. Of these, the mycorrhizal (plantfungal) symbiosis is ancient, having evolved over 4.5 million years into a tight mutualism (generally speaking, but there is a continuum in the symbiosis between mutualism and parasitism; Jones \& Smith, 2004). The mycorrhizal symbiosis involves thousands of fungal species world-wide (Molina et al., 1992). Mycorrhizas are universally present in all terrestrial biomes, including native forests, woodlands, savannas, grasslands and tundra (Smith \& Read, 1997). The three dominant groups are ectomycorrhizas (ECM, primary on trees and shrubs in boreal and temperate ecosystems), ericoid mycorrhizas (ERM, primarily on Ericaceae species in high latitude and high altitude ecosystems), and arbuscular mycorrhizas (AM, primarily on grasses, herbs and tropical tree species).

Many mycorrhizal taxa associate with a broad range of plant species, and thus are considered host generalists. Most fungi in the AM group are considered host generalists, whereas fungi in the ECM and ERM groups include both host generalists and host specialists (i.e., that associate with a narrow group of plant species) (Molina et al., 1992). The low host specificity of many mycorrhizal taxa allows a single mycorrhizal fungal mycelium to link the roots of two or more plants of one or more species in a mycorrhizal network. Increasingly, mycorrhizal networks are recognized as ubiquitous in terrestrial ecosystems, including tropical, temperate and boreal forests (van der Heijden \& Horton, 2009). Mycorrhizal networks can function in the mycorrhizal colonization of new seedlings, spread of fungal mycelia, or transfer of carbon, nutrients or water between plants (Simard et al., 2002), thus affecting plant and fungal community dynamics. The architecture of mycorrhizal networks can follow regular, random or scale-free models. In both regular and random networks, links (e.g., fungi) tend to be distributed equally among nodes (e.g., trees). In scalefree models, however, some nodes (e.g., hub trees) are highly linked (Bray, 2003). The architecture of the network reflects its resilience against disturbance (e.g., removal of trees). All mycorrhizas take up nutrients and water from the soil in exchange for photosynthate carbon from host trees. Photosynthate carbon has been shown to transfer from host plants to mycorrhizal hyphae within hours (Johnson et al., 2002) and this drives half of the belowground microbial activity, with the rest fueled by heterotrophic metabolism of dead organic matter (Högberg \& Högberg, 2002). Plants invest photosynthate carbon in mycorrhizas (instead of building their own roots) because the small and profuse hyphae have 60 times more absorptive area than fine roots (Simard et al., 2002). Generally, as nutrient and water limitations increase, plants allocate more photosynthate to mycorrhizal hyphae to increase soil resource uptake. This explains their increasing dominance (relative to bacteria) in high latitude, high altitude or upslope ecosystems (Hobbie, 2006; Högberg et al., 2007). In turn, colonization by mycorrhizal fungi has been shown to up-regulate photosynthesis (Rygiewicz \& Anderson, 1994; Miller et al., 2002).

A large portion of photosynthate carbon is allocated belowground and metabolized by roots, mycorrhizal fungi and heterotrophic organisms. The proportion of carbon that is allocated belowground to roots and mycorrhizas has been shown to range from $27-68 \%$ of net primary productivity (NPP) in ECM culture studies (Hobbie, 2006). The proportion of carbon allocated directly to mycorrhizal fungi ranges from $1-21 \%$ of total NPP (Hobbie, 2006). The amount allocated to root exudation represents $1-10 \%$ of NPP, and is important in fueling soil foodwebs and soil organic matter formation (Cardon \& Gage, 2006). 
Mycorrhizal fungi have a diversity of functions in carbon metabolism. They not only directly access mineral nutrients and water in soil in exchange for photosynthate, they can also decompose soil carbon for energy and nutrient uptake. For example, mycorrhizal fungi have been shown to assimilate simple organic compounds (e.g., amino acids) from the soil solution while in symbiosis (Näsholm et al., 1998). Recently, ECM fungi, ERM fungi and, to a lesser extent AM fungi, have also been found to act as decomposers of larger organic molecules (e.g., proteins, chitin, pectin, hemicellulose, cellulose, polyphenols) by producing extracellular enzymes (e.g., proteases, polyphenol oxidases) (Read \& Perez-Moreno, 2003; Tu et al., 2006; Talbot et al., 2008). Talbot et al. (2008) proposed three conditions under which mycorrhizas act as decomposers: (1) when plant photosynthate is low (e.g., in shade, winterearly spring, or when plants are declining) and mycorrhizas require an alternative energy source, (2) when soils are highly organic (e.g., at high latitude or high altitude) and mycorrhizas are required to mine organic nutrients, or (3) when plant productivity is high (especially in crop plants), and mycorrhizal decomposition is primed by large belowground photosynthate carbon fluxes. The model of Talbot et al. (2008) differs from the traditional decomposition model where saprotrophic fungi were considered exclusively responsible for all soil organic matter decomposition. In addition to saproptrophs, however, different taxa of mycorrhiza fungi are now recognized as targeting different carbon sources, implying niche partitioning. This niche partitioning can help explain why such a dazzling diversity of fungi are involved in carbon and nutrient metabolism in soils (Hansen et al., 2008). It also points to the importance of understanding the diverse roles of plants and fungi in global carbon flux dynamics.

Arbuscular mycorrhizal fungi generally do not break down soil organic matter, but they do play important roles in promoting soil aggregation and soil carbon storage. Soil aggregation occurs when hyphae pervade soil pores and entwine soil particles. Mycorrhizal hyphal growth in soils is extensive, with mycelial lengths reaching $111 \mathrm{~m} \mathrm{~cm}^{-3}\left(0.5 \mathrm{mg} \mathrm{g}^{-1}\right.$, or up to $900 \mathrm{~kg} \mathrm{ha}^{-1}$ ) in a prairie soil (Miller et al., 1995). Though AM hyphae turn over quickly (in days to a few months), they also deposit significant quantities of relatively recalcitrant carbon compounds such as chitin and glomalin. Glomalin is a carbon-, nitrogen- and ironrich glycoprotein produced in fungal cell walls (Treseder \& Turner, 2007). When it is deposited during decomposition, glomalin joins hyphae in binding small soil particles, thus promoting aggregation and soil stability. Although it constitutes only $0.4-6 \%$ of hyphal biomass, glomalin accumulates in soil macro-aggregates at much higher masses (e.g., $>100$ $\mathrm{mg} \mathrm{g}^{-1}$ ) than does hyphae. In soil aggregates, glomalin carbon is protected from decomposition by chemicals and soil organisms, allowing it to remain in soils for decades and accumulate over time (Rillig et al., 2001; Zhu \& Miller, 2004). Carbon in bulk soil, by contrast, is more vulnerable to decomposition. Hence, AM glomalin represents a large pathway for storage of stable carbon in soils. Glomalin content of soils generally increases with the abundance of AM plants and carbon allocation to AM hyphae, and has been shown to represent $3-8 \%$ of soil carbon in undisturbed AM grassland and chaparral communities (Rillig et al., 2001).

The composition of mycorrhizal communities shifts with changes in the balance of carbon and nutrients in soils because of fungal species variation in demands for carbon, nitrogen and phosphorus. For example, increases in carbon allocated belowground with $\mathrm{CO}_{2}$ enrichment or warming may shift the mycorrhizal community toward dominance by high biomass fungi with proteolytic or long-distance exploration capabilities that enable them to 
compete for scarce nutrients or contribute to soil carbon storage (Treseder, 2005; Hobbie \& Hobbie, 2006). These fungi are also considered important in forming mycorrhizal networks with high transfer capacity (Simard \& Durall, 2004). In the next section we discuss how climate change can trigger such shifts in the mycorrhizal fungal community.

\section{Effects of climate change factors on mycorrhizal fungi}

Climate change is resulting in increasing atmospheric $\mathrm{CO}_{2}$ concentrations, increasing soil nutrient availability, regional warming and regional drying as a result of fossil fuel burning, land use change, and nutrient pollution. These changes are having multi-faceted effects on plants, mycorrhizal fungi and ecosystems. In this section, we review the key climate factors individually and their potential effects on mycorrhizal fungi.

\subsection{Atmospheric $\mathrm{CO}_{2}$ enrichment}

Carbon as atmospheric $\mathrm{CO}_{2}$ has increased from a pre-industrial level of $280 \mathrm{ppm}$ to $392 \mathrm{ppm}$ in 2010 (Keeling, 1998; IPCC, 2007; http://co2now.org/). The most important effects of atmospheric $\mathrm{CO}_{2}$ enrichment on mycorrhizal fungi are expected to be indirect through their impacts on plants (Staddon \& Fitter, 1998). Plants generally respond to $\mathrm{CO}_{2}$ enrichment with increased photosynthesis, decreased stomatal conductance, and increased net primary productivity (Poorter, 1993). They also distribute greater amounts of carbon belowground to roots, mycorrhizas, soil foodwebs and exudates (Pritchard et al., 2008; Drigo et al., 2008), due either to greater productivity or shifts in allocation patterns (Zak et al., 2000). Increased availability of carbon to mycorrhizas belowground is considered an important strategy for plants to meet their increasing needs for nutrients and water (Bazazz, 1990; Rogers et al., 1994). In addition to these predicted shifts, mycorrhizal function may also change with increasing $\mathrm{CO}_{2}$, resulting in lower net carbon costs or increased nutrient-uptake benefits for host plants (Johnson et al., 2005). In addition to acquiring carbon, mycorrhizal fungi also mediate the return of $\mathrm{CO}_{2}$ to the environment through metabolism and decomposition. The degree to which the increased carbon allocated belowground is rapidly released as $\mathrm{CO}_{2}$ or allocated to a more recalcitrant soil pool is not well understood.

In keeping with the above predictions, Treseder (2004) found in a meta-analysis of field studies that mycorrhizal abundance increased on average by $47 \%$ (84\% for AM fungi; $19 \%$ for ECM fungi) with increased atmospheric $\mathrm{CO}_{2}$ concentration; these increases occurred irrespective of biome, level of $\mathrm{CO}_{2}$ enrichment or measurement method. Meta-analyses are powerful tools that can be used to detect general responses in ecosystems that are often difficult to isolate in individual studies. Individual studies are still critical, however, in uncovering sources of variation and response mechanisms. In long-term $\mathrm{CO}_{2}$ enrichment experiments, for example, Allen et al. (2005) and Treseder et al. (2003) were able to determine that $\mathrm{AM}$ fungal abundance response increased with $\mathrm{CO}_{2}$ enrichment and peaked at 550-650 ppm. (Some caution is needed in interpreting such experiments because abrupt rises in $\mathrm{CO}_{2}$ enrichment can over-estimate mycorrhizal responses (Klironomos et al., 2005)). Treseder et al. (2003) also determined that net ecosystem exchange to the atmosphere declined with increasing $\mathrm{CO}_{2}$, where the extra carbon was added to bulk soil and, to a greater degree, soil macro-aggregates through increased AM hyphal growth and glomalin production. Staddon et al. (1999) also showed that AM fungi stimulated carbon flow belowground with elevated $\mathrm{CO}_{2}$, but they estimated that most of this belowground carbon 
was respired. Allen et al. (2005) found that the standing crop of fungi, bacteria and soil organisms did not increase with elevated $\mathrm{CO}_{2}$ in arid chaparral ecosystems, but they speculated that microbial turnover increased in response to increased carbon allocation belowground. A few other studies have found no effect or even reduced AM fungal colonization with increased $\mathrm{CO}_{2}$ levels (Staddon \& Fitter, 1998). Though the meta-analysis of Treseder (2004) showed strong trends, clearly there are multiple environmental and species influences on mycorrhizal responses to elevated $\mathrm{CO}_{2}$ that remain to be explored.

Enrichment of $\mathrm{CO}_{2}$ is expected to cause shifts in mycorrhizal community composition. These shifts will depend on the relative abilities of different fungal taxa to exploit carbon, nitrogen and phosphorus pools, or to acclimatize to the changing environment. Where elevated $\mathrm{CO}_{2}$ increases belowground carbon allocation and stimulates nutrient deficiencies, "late stage" or medium or long distance "exploration types" of mycorrhizal fungi may be favoured because of their specific exploration strategies for accessing immobile or distant nutrient patches (Agerer, 2001; Hobbie \& Agerer, 2010). Where phosphorus is limiting in particular, fungi that invest more carbon into hyphal branching should be favoured because of the relative immobility of this nutrient (Treseder, 2005). In environments where nitrogen is more limiting, however, fungal groups that invest in rhizomorphs that forage over long distances to nitrogen-rich patches should be favoured. Other mycorrhizal fungal taxa may also be favoured in these low nutrient environments because of their adaptations for producing extracellular enzymes to decompose soil organic complexes (see above), or for cultivating associative N-fixing bacteria in their hyphosheres in exchange for nitrogen (Agerer, 2001; Treseder, 2005). Studies examining ECM communities under the low nutrient conditions expected under $\mathrm{CO}_{2}$ enrichment have found shifts toward morphotypes dominated by extraradical hyphae, rhizomorphs and thin fungal sheaths, and to communities dominated by Cortinarius, Suillus, Tricholoma or Cenococcum (Lilleskov et al., 2001 and 2002; Treseder, 2005). These exploration fungal types are also considered important in the formation of mycorrhizal networks and transfer of nutrients between plants, suggesting that elevated $\mathrm{CO}_{2}$ may favour the development of more extensive networks that link plants over long distances.

In addition to its effect on the composition of mycorrhizal communities, elevated $\mathrm{CO}_{2}$ has also been shown to alter the composition of the broader soil microbial community (Allen et al., 2005). Increased carbon allocation to roots and mycorrhizas stimulates soil foodweb activity, but variation in the amount and quality of carbon can favour specific members of the foodweb. For example, saprotrophic fungi have been shown to increase in abundance with rising $\mathrm{CO}_{2}$ because of greater inputs of root and leaf litter to the soil (Parrent \& Vilgalys, 2007). Modifications in litter chemistry, including increases in lignin concentrations with increasing $\mathrm{CO}_{2}$ levels (Norby et al., 2001), should also have consequences for soil microbial communities (Bradley et al., 2007).

\subsection{Soil nutrient enrichment}

Nutrient availability is generally increasing in two ways with global change: through localized anthropogenic nutrient deposition via fertilization and pollution and, to a lesser extent, through increased microbial decomposition with soil warming. Although global change is having the strongest impact on the nitrogen cycle, soil warming has the potential to affect the availability of all soil nutrients. Nitrogen deposition specifically has increased by 3-5 times through industrial fixation and fossil fuel burning, and now exceeds levels of 
natural nitrogen fixation world-wide (Vitousek, 1994). Because plant productivity is nitrogen-limited globally, NPP has increased and plant distributions have shifted in response to nitrogen enrichment (Vitousek, 1994; Treseder et al., 2005). Currently most nitrogen deposition is in the temperate regions of the USA and Europe, where nitrogen is considered most limiting, but future nitrogen deposition is expected to increasingly occur in the tropics (Dentener et al., 2006). Nutrient enrichment through soil warming can result in increased NPP, but this may ultimately be limited by depletion of the soil nutrient capital (e.g., phosphorus).

In global change studies, scientists have investigated nitrogen enrichment effects on plants and mycorrhizas along nitrogen deposition gradients, in fertilization experiments, and in experiments that have artificially increased soil temperature. These studies have generally shown positive effects of nitrogen enrichment on aboveground plant productivity but negative effects on the belowground foodweb (Treseder et al., 2004). As soil nutrient availability increases, plants have less need for investing carbon into roots, mycorrhizas and microbial activity for nutrient uptake, and therefore they allocate more carbon to aboveground biomass. A recent meta-analysis has indeed shown that industrial nitrogen deposition not only stimulated aboveground forest growth (Thomas et al., 2010), but also reduced soil microbial activity, diversity and soil organic matter decomposition, thus stimulating carbon sequestration in temperate forests (Janssens et al., 2010). Congruently, in a meta-analysis of field fertilization studies, (Treseder, 2004) found that mycorrhizal biomass declined on average by $15 \%$ with soil nitrogen enrichment $(25 \%$ decline in AM biomass versus $5 \%$ decline in EM biomass) and by $32 \%$ with soil phosphorus enrichment. Similar declines $(15 \%)$ in total microbial biomass (fungi plus bacteria) with nitrogen additions were observed in a separate meta-analysis of 82 field studies, with greater declines where fertilizer was added over longer periods and at higher amounts (Treseder et al., 2008). Janssens et al. (2010) caution, however, that saturating levels of nitrogen deposition could lead to declines in forest productivity, both above- and belowground, because of soil acidification, leaching of ions and nitrogen, and increasing phosphorus deficiencies. These negative effects may overwhelm any positive effects of nitrogen deposition world-wide, particularly in tropical forests where phosphorus is the primary limitation to tree growth.

Fertilization studies suggest that smaller changes tend to occur in ECM than AM fungal communities and in deciduous than coniferous forests (Peter et al., 2001; Aber et al., 2003; Treseder et al., 2007; Vitousek et al., 2008). Correspondingly, ECM fungal diversity and richness declined in coniferous forests along a nitrogen deposition gradient (Lilleskov et al., 2002), but appeared to decline to a lesser degree in deciduous forests (Arnolds, 1991). The differences in these responses is likely related to the degree to which plant species are nitrogen or phosphorus limited, the diversity of associated fungal species, and the availability of soil mineral and organic nitrogen (Talbot et al., 2008). For example, many deciduous tree species are more nutrient-rich than coniferous species (Simard et al., 1997a; Jerabkova et al., 2006), and should therefore be less sensitive to nutrient additions. In addition, AM plants generally occur in more nutrient rich environments (Smith \& Read, 1997), but the wider diversity of fungi that ECM plants host for accessing nutrients may provide a degree of functional similarity that buffers the community against increases in nutrient availability (Jones et al., 2010).

Where nutrients are elevated, "early stage", contact or short distance "exploration types" of mycorrhizal fungi may be favoured because of their ability to rapidly colonize new 
seedlings and exploit nutrient-rich environments (Deacon \& Donaldson, 1983; Hobbie \& Agerer, 2010). When plants are initially establishing on disturbed or enriched sites, carbon can be briefly limiting to mycorrhizal growth. Under these conditions, mycorrhizal taxa that allocate more biomass to exchanges sites, such as arbuscules in AM fungi, or the Hartig net in ECM fungi, or those taxa that can acquire carbon from alternate sources, may also be favoured (Treseder, 2005). The decline in ECM fungal diversity observed by Lilleskov et al., (2001, 2002) along a nitrogen deposition gradient corresponded with a shift toward early successional fungi such as Laccaria, Paxillus and Lactarius that posess these characteristics. Early successional fungi have been shown to form mycorrhizal networks in forests and facilitate carbon and nitrogen transfer over short distances (Simard et al., 1997a), but to a smaller degree than later successional fungi (Teste et al., 2009a). Reductions in mycorrhizal richness, whether involving early or later successional fungi, reduces the complexity of mycorrhizal networks, which has corresponded with lower rates of nutrient transfer and survival of establishing seedlings in temperate forests (Teste et al., 2009a).

Nitrogen deposition can not only reduce mycorrhizal activity and diversity, but it can also favour specific saprotrophic communities (Janssens et al., 2010). After 19 years of annual fertilization at Toolik Lake, Alaska, for example, Deslippe et al. (2010) found an increase in the abundance of saprotrophs and small changes in the ECM fungal community. The increasing group of saprotrophs (as discussed by Janssens et al. (2010)) can be superior at producing cellulose-decomposing and phosphate-acquiring enzymes, but not be very efficient at producing lignin-degrading enzymes. Ironically, the saprotrophs can therefore leave more recalcitrant organic matter, ultimately leading to greater accumulation of soil carbon and reducing respiration. Studies show that a large fraction of this soil organic matter is chemically or physically protected from further microbial decay, particularly where it is associated with clay particles. It is important to note that the more decay resistant carbon is the result of saprotrophic biochemical transformations rather than increased soil aggregation; this is because mycorrhizal abundance and rhizodeposition generally decline with increasing nitrogen availability. The long-term stability of these changes in soil carbon is therefore uncertain.

\subsection{Soil warming}

Plant growth generally increases with soil temperature, but it can also decline where nutrient deficiencies are induced or soil water availability is reduced through increased rates of evapo-transpiration (Pendall et al., 2004). Where plant productivity increases with soil temperature, mycorrhizal and microbial activity are also predicted to increase to help meet increasing nutrient and water demands (Pendall et al., 2004). In keeping with these predictions, mycorrhizal fungal abundance has been shown to increase with soil warming. However, they have also declined initially where limiting thresholds of nutrient or water availability were exceeded (Rustad et al., 2001). Thus, temperature effects on mycorrhizal activity can be mediated through nutrient and water cycles.

Plants and mycorrhizas are not necessarily limited by the same resources at the same time, and feedbacks between climate change factors will mediate plant, mycorrhizal and soil responses to warming (Hobbie, 2000; Pendall et al., 2004). Moreover, plants and mycorrhizal fungi may acclimate to soil temperature changes (Allison et al., 2010). This suggests we should expect variable effects of soil warming on mycorrhizal fungi depending on the type of plant community, the length of time since warming, and feedbacks among different 
climate processes. For example, mycorrhizal fungal growth increased following 14 years of warming in the Arctic tundra at Toolik Lake, Alaska (Clemmenson et al., 2006) but declined in mature black spruce forests of Alaska (Allison and Treseder, 2008). After 19-years in the warming treatment at Toolik Lake, Deslippe et al. (2010) found that ECM colonization of the dominant tundra shrub, Betula nana, had returned to control levels, suggesting the ECM community had acclimatized to the new conditions. However, they also found an increase in high biomass mycorrhizal fungi with proteolytic capacity, especially Cortinarius, and a reduction in fungi with high affinities for nitrogen, especially Russula, supposedly reflecting Betula nana's increased demand for nutrients bound in soil organic matter with warming. In the black spruce forest, the decline in fungal biomass likely coincided with reductions in soil moisture and increases in nitrogen availability. Exceeding minimum thresholds in soil moisture due to evapotranspiration appears to constrain the predicted mycorrhizal increases with warming, and this ought to occur more commonly in dry than moist forests or than moist tundra underlain by permafrost.

The positive effects of soil warming on the abundance of mycorrhizal fungal taxa with high biomass and long distance exploration types found by Deslippe et al. (2010) suggests that soil warming should promote development of larger mycorrhizal networks. At Toolik Lake, Deslippe \& Simard (2010) found that mycorrhizal networks transferred fixed carbon between Betula nana shrubs, but not to other plant species, and the amount was potentially sufficient to affect the performance of Betula nana. Development of larger mycorrhizal networks with warming should therefore favour community dominance by Betula nana and may help explain its current expansion on the Arctic tundra with warming. The increase in carbon uptake throught expansion of Betula nana in the tundra, however, will likely be exceeded by carbon release resulting from permafrost thawing effects (Schuur et al., 2009).

In addition to general increases in mycorrhizal biomass with soil temperature, increases in microbial activity should lead to increases in soil organic matter decomposition. This is because microbes produce extracellular enzymes that catalyze the conversion of soil organic matter to dissolved organic carbon, which is the rate-limiting step in decomposition (Allison et al., 2010). The increase in decomposition with soil warming is speculated to offset the increases in carbon allocation belowground with increased atmospheric $\mathrm{CO}_{2}$. In keeping with this expectation, soil $\mathrm{CO}_{2}$ and $\mathrm{CH}_{4}$ emissions have been found to initially increase in soil warming experiments. However, emission rates have been found to then decline back to control levels within a few years once microbes acclimate to the elevated temperature and allocate less carbon toward biomass growth (i.e., they reduce their carbon-use efficiency) (Allison et al., 2010). The short-term nature of respiration increases have also resulted partly from rapid depletion of labile carbon pools (Bradford et al., 2008).

\subsection{Reduced soil water availability}

Reduced precipitation predicted for mid-latitude ecosystems will likely result in increasing water limitations to plant growth (IPCC, 2007). When soil water availability declines, plants should allocate more carbon to mycorrhizal fungi so that they can access scarce soil water (Augé, 2001). Conversely, in areas where precipitation increases, less plant carbon should be allocated to mycorrhizal growth. Studies show that drier conditions have tended to increase arbuscular mycorrhizas as predicted but have had variable effects on ectomycorrhizas (Allison \& Treseder, 2008). While water limitations are generally expected to increase with climate change, increases in water use efficiency may buffer some of the negative effects of 
drought. For example, colonization with mycorrhizal fungi can increase plant water use efficiency due to improved phosphorus nutrition (Augé, 2001). Water-use efficiency of plants has also been shown to increase with atmospheric $\mathrm{CO}_{2}$ (Bazazz, 1990).

\subsection{Overall climate change effects}

The inter-related effects of climate change factors on forest ecosystems, plants and mycorrhizal fungi are complex and difficult to predict. The results of field studies generally suggest that increased $\mathrm{CO}_{2}$, soil warming and soil drying should increase plant carbon allocation to mycorrhizas and shift the fungal community to species characterized by high biomass, long distance exporation strategies, and proteolytic capabilities for meeting nutrient demands. These mycorrhizal types should favour development of mycorrhizal networks, which would promote tree species establishment and survival, but they should also have greater decomposition capabilities. Conversely, nutrient enrichment should reduce mycorrhizal fungal abundance and favour early successional mycorrhizal species that are nitrophillic and with more limited networking capacity. This may limit growth of older trees or promote invasion of weedy plants that are less reliant on mycorrhizal fungi for meeting their resource needs. On balance, the present state of knowledge regarding climate change trajectories suggests that forest health will decline in the future and forest soils will become a net source of atmospheric $\mathrm{CO}_{2}$ (Jones et al., 2004; Pendall et al., 2008; Kliejunas et al., 2009; Kurz et al., 2008a). Changes at high latitudes, including thawing and warming of Arctic and boreal soils are especially at risk of strong positive $\mathrm{CO}_{2}$ and $\mathrm{CH}_{4}$ feedbacks to the atmosphere (Schuur et al., 2009), as is evidenced by the recent shift in Arctic soils from being a net carbon sink to a net carbon source (Apps et al., 2005). This has the potential to greatly amplify climate change in the near future (Schuur et al., 2009).

Climate change factors could also alter the functional roles of mycorrhizal species in soil carbon dynamics (e.g., as vectors, scavengers or decomposers) (Talbot et al., 2008). Similarly, these changes could shift the compatibility and cooperation between hosts and fungi along the mutualism-parasitism continuum, and the relative fitness of various mycorrhizal fungi and other microbes that currently protect roots or suppress root disease (Kiers \& van der Heijden, 2006; Hoeksema \& Forde, 2008; Kliejunas et al., 2009). Specific changes in plant growth and physiology, population genetics, and interactions with changes in the mycorrhizal community, will also affect interplant interactions, plant community composition, and mycorrhizal fungal community composition. Therefore, the direct and indirect effects of climate change on both plants and mycorrhizas should have direct consequences for the global carbon balance.

\section{Effects of climate change on forests and their mycorrhizal communities}

The effects of climate change on forests are expected to be profound (Aber et al., 2001; Dale et al., 2001). Climate change is expected to affect tree species and forest distributions, forest dynamics and succession, the interactions and co-evolution between trees, mycorrhizal fungi and other mutualists, and ecosystem function (Malcolm et al., 2006; Hamann \& Wang, 2006; Whitham et al., 2006). Forest productivity can change slowly in response to the relatively slow and directional changes in mean $\mathrm{CO}_{2}$ levels, temperature and precipitation, but it can also change rapidly in response to extreme events (e.g., drought, fire, insect outbreaks), which are occurring with greater frequency and severity world-wide (IPCC, 
2007; Liu et al., 2010). There are currently 120 documented cases of forest dieback worldwide that are directly attributed to climate change (Allen et al., 2010). Forest decline resulting from climate change, whether due to slow increases in stress or sudden diebacks, has the potential to transform soil microbial communities and cause massive $\mathrm{CO}_{2}$ feedbacks to the atmosphere. The dieback of 12 million hectares of lodgepole pine due to the mountain pine beetle epidemic in British Columbia, for example, has changed these forests from a net sink to a net source of carbon to the atmosphere (Kurz et al., 2008a).

In the Northern Hemisphere, the distribution of plant communities is expected to change dramatically and idiosyncratically over the next century. The IPCC (2007) generally predicts a northward migration of the boreal and temperate forests, an expansion of prairie and shrub-lands, and a dramatic reduction in the taiga and Arctic tundra. In British Columbia, climate models predict that the sub-boreal, montane and subalpine forests will almost disappear by 2100 , while the grasslands and temperate forests will greatly expand to the north (Hamann \& Wang, 2006; Spittlehouse, 2008). For each $1^{\circ} \mathrm{C}$ increase in temperature, forest zones will have to move $160 \mathrm{~km}$ (Petit et al., 2004; Hamann \& Wang, 2006); for an increase in $4^{\circ} \mathrm{C}$ over the next century, species in the Northern Hemisphere may have to move northward by $500 \mathrm{~km}$ (or $500 \mathrm{~m}$ higher in altitude), or a few kilometers per year to find a suitable habitat (IPCC, 2007). This far outpaces the historical tree migration rate of 100-200 m per year estimated from pollen records and chloroplast DNA analyses (MacLachlan \& Clark, 2004). If tree species are unable to migrate as predicted or adapt rapidly, they will face extirpation (Aitken et al., 2008). Gene flow of pre-adapted alleles from warmer climates will help tree species migrations at the leading edges of their ranges; however, populations at the rear edges will have greater chance of dieback due to lags in adaptation and migration ability (Aitken et al., 2008). Diebacks and declines are already evident in North American species such as paper birch, trembling aspen, ponderosa pine, pinyon pine and lodgepole pine (Hogg et al., 2002; Mueller et al., 2005; Bouchard et al., 2008; Heineman et al., 2010). Conversely, northward or upward migration is evident in lodgepole pine, white spruce and green alder (Johnstone \& Chapin, 2003; Danby \& Hik, 2007).

Mycorrhizal fungi, through their obligate role in tree establishment, survival and growth, will play a key role in the conservation of core native forests, minimizing diebacks of forests at the trailing edges of tree species ranges, and facilitating migration of tree species at the leading edges of their ranges. Mycorrhizal networks, and their role in mycorrhization and mediation of resource distribution among trees according to need, will likely play a key role in maintaining both the integrity and reorganization of old and new forests. In the next section, we describe how mycorrhizal networks play an important role in the selforganization and stability of forests.

\section{Role of mycorrhizal networks in forest stability with climate change}

In this section, we argue that the most important role of mycorrhizas with climate change may be in their stabilizing effects on forests that are under increasing environmental stress. The functional significance of mycorrhizal fungi at these higher levels of ecosystem organization is increasingly recognized, including the role of mycorrhizal networks in forest regeneration, succession and resistance against exotic invasions (Nara \& Hogetsu, 2004; Simard \& Durall, 2004; Selosse et al., 2006; McGuire et al., 2007; Simard, 2009). Mycorrhizal networks may thus provide a community-based model for feedback pathways that promote 
forest stability with climate change. We explore this concept with our research on mycorrhizal networks in the interior Douglas-fir forests of British Columbia.

Interior Douglas-fir forests vary widely in composition and structure, from predominantly single-species, uneven-aged forests in the arid and cool climatic regions, to multi-species, even-aged forests in the moist, warm climatic regions of British Columbia. Regardless of this variation in forest composition and structure, Douglas-fir is a dominant tree species. The composition of the fungal community changes with succession, where a few pioneering taxa such as Wilcoxina rehmii and Mycelia atrovirins radicans dominate the roots of Douglas-fir germinants in the first few years following wildfire or harvesting disturbances (Jones et al., 1997; Teste et al., 2009a; Barker et al., 2010). This is followed by rapid succession to a more diverse, late-stage ECM fungal community increasingly dominated by the Rhizopogon vinicolor/R. visiculosus complex (Twieg et al., 2007). The Rhizopogon complex joins up to 63 other ectomycorrhizal species in a complex fungal community colonizing interior Douglasfir (Twieg et al., 2007). Even with shifts in ECM fungal species composition with disturbance and succession, there is enough functional similarity among taxa that total enzyme production by the community remains unchanged (Twieg et al., 2009; Jones et al., 2010). Congruently, seedling nutrient uptake and growth remain stable over a wide range of disturbance severities (Barker \& Simard, 2010).

Early and late successional ECM fungi form mycorrhizal networks linking together Douglas-fir trees of many ages in the arid temperate forests (Teste et al., 2009b, Beiler et al., 2010). Douglas-fir can also form linkages with several other tree and shrub species in these forests (Simard et al., 1997b; Hagerman et al., 2001; Twieg et al., 2007). In a dry, uneven-aged interior Douglas-fir forest, we used multi-locus, microsatellite DNA markers to determine that all Douglas-fir trees were interconnected and that the young trees had regenerated within the extensive Rhizopogon network of old veteran Douglas-fir trees (Beiler et al., 2010). Most of the young trees were linked to large, old hub (i.e., highly connected) trees, suggesting the network had scale-free properties; thus, the hub trees were important in selfregeneration of the old-growth forests. In similar forests nearby, we examined this experimentally and showed that seedling establishment success increased by four times where they had full access to the mycorrhizal network of older Douglas-fir trees (Teste \& Simard, 2008; Teste et al., 2009b). Access to the network not only improved seedling survival and physiology, but seedlings were colonized by a more complex fungal community and received carbon, nitrogen and water transferred from the older trees (Schoonmaker et al., 2008; Teste et al., 2009a,b). The finding that the network had scale-free properties suggests they were robust against random removal or death of individual trees, which would have little effect on the connectivity of the network (Bray, 2003). By contrast, targeted removal of hub trees, such as through high-grade logging, or insects that selectively attact large trees (e.g., bark beetles), would have negative effects on the regeneration system. In fact, network models have shown that removal of highly connected nodes can cause the scale-free network to stop functioning (Bray, 2003). Random networks, where links are distributed equally among nodes, such as those found in the widely spaced Quercus garryana forests of California (Southworth et al., 2005) are conversely more likely to unravel from random tree removal.

The mixed Douglas-fir - paper birch stands in the moist, warm Interior Cedar-Hemlock forests are more productive and regenerate more readily after disturbance than do the pure Douglas-fir stands of the dry forests (Simard et al., 2005), but mycorrhizal networks also 
play a role in Douglas-fir regeneration. In the understory of century-old paper birch and Douglas-fir mixtures, establishment success of Douglas-fir has increased where seedlings were linked into the mycorrhizal network of older trees (Simard et al., 1997b). There, greater regeneration success was associated with seedling colonization by a more complex mycorrhizal network associated with the mature trees (Simard et al., 1997b). In nearby clearcuts, Douglas-fir seedlings have also benefited from simple mycorrhizal networks by receiving carbon from neighbouring paper birch, particularly where Douglas-fir was shaded (Simard et al., 1997a). Net carbon transfer followed a source-sink photosynthate gradient, from carbon- and nutrient-rich paper birch source seedlings to increasingly light-stressed Douglas-fir sink seedlings. Traditional models of forest dynamics predict that regeneration patterns are controlled by competitive interactions with neighbours (Oliver \& Larson, 1997), but this study showed that facilitation by networks increased regeneration performance and affected interspecific interactions between paper birch and Douglas-fir, encouraging a more diverse tree community. These tree-species-rich forests are also more resilient to insect attack and disease than pure Douglas-fir forests, as shown when deciduous species are removed by weeding or thinning (Morrison et al., 1988; Baleshta et al., 2004; Simard et al., 2005).

Forest ecosystems are dynamic, and this is illustrated by dynamic patterns and processes in mycorrhizal networks. Not only do the complexity and composition of mycorrhizal networks change over time (Twieg et al., 2007), but belowground fluxes of nutrients change over the growing season with shifts in source-sink gradients among networked plants (Lerat et al., 2002). Using dual ${ }^{13} \mathrm{C} /{ }^{14} \mathrm{C}$ labelling in the field, Philip (2006) found that the direction of net carbon transfer reversed twice over the growing season: (1) from shooting Douglas-fir to bud-bursting birch in spring; (2) then reversing, from nutrient and photosynthateenriched paper birch to stressed understory Douglas-fir in summer; and (3) reversing again, from still-photosynthesizing Douglas-fir to senescent paper birch in the fall. The carbon moved back-and-forth between birch and fir through multiple belowground pathways, including mycorrhizal networks, soils, and a non-networked mycorrhizal-soil pathway (Philip et al., 2010). Here, there appears to be a dynamic interplay between birch, fir and the interconnecting fungi, with carbon and nutrients moving in the direction of greater need over the growing season, resulting in an integrated, dynamic system.

Where severe disturbances remove forest floor and trees in dry climates, mycorrhizal networks are disrupted, resulting in greater reliance of new germinants on mycorrhizal colonization by spores or mycorrhizal fragments in the soil (Teste et al., 2009a; Barker et al., 2010). Although severe disturbances are part of the historic mixed fire regime in the interior Douglas-fir forests, they have usually been infrequent and restricted to small patches (Klenner et al., 2008). As the climate of these forests becomes warmer and drier (Hamann \& Wang, 2006), severe disturbances are expected to increase in extent and frequency (Dale et al., 2001), raising concerns about mycorrhizal spore production and dispersal into the disturbed areas. Production of fruiting bodies declines in dry summers (Durall et al., 2006), and belowground dispersal of spores by truffle-forming species such as Rhizopogon may be limited over extensive openings. Douglas-fir seed rain and regeneration have also been sporadic in these forests (Vyse et al., 2006), and the resulting regeneration lags in dry summers could cause local extinction of Rhizopogon and other network-forming ECM fungal taxa. Nevertheless, early successional ECM fungi are host-generalists, and they will continue to play a critical role in seedling establishment following disturbance. 
In spite of the greater risk of severe fires disrupting networks in arid climates, the stressgradient hypothesis suggests that biotic facilitation of Douglas-fir regeneration by mycorrhizal networks should be even greater in stressed environments. We tested this hypothesis along an environmental stress gradient caused by soil disturbance in the dry interior Douglas-fir forests. We found that naturally regenerated Douglas-fir seedlings received more transferred carbon through mycorrhizal networks from their neighbours where soils were disturbed by forest floor removal and compaction than where soils were undisturbed, but only where the seedlings were initially well colonized by EM fungi (Teste et al., 2010). Here, disturbance created a sufficient source-sink gradient between seedlings for carbon transfer to occur, but receiving seedlings also had to be healthy and colonized well enough to generate adequate sink strength. We are also testing network facilitation along a regional precipitation gradient across the interior Douglas-fir forests, from the very dry climate of the Interior Douglas-fir zone to the moist climate of the Interior CedarHemock zone (M. Bingham, unpublished data); this regional climate gradient is serving as a proxy for climate change. Early results suggest that, as expected, older Douglas-fir trees transferred more carbon through Rhizopogon-dominated mycorrhiza networks, and thus facilitated tree regeneration more strongly, in dry than in wet climates. A decade of drought combined with western spruce budworm and Douglas-fir bark beetle attack, however, has resulted in extensive dieback of these older trees (Campbell et al., 2003; Maclauchlan et al., 2007). Extensive hub tree mortality in some stands may be exceed thresholds where Rhizopogon networks are no longer sufficiently intact to facilitate regeneration (M. Bingham, unpublished data). Simpler networks comprised of early successional fungi, however, ought to continue to play a critical role in regeneration after disturbance (Barker et al., 2010).

\section{Facilitating the stabilizing effects of mycorrhizas through forest management}

\subsection{Historical management practices}

Forest management practices that sequester carbon include conservation of native forest, siliviculture practices that emulate natural processes, reforestation of crop-lands, manipulations of tree chemistry to favour lignin, and changes to the soil microbial community. Conversely, those forest management practices that result in net losses of soil organic matter include deforestation or conversion of native forests to plantations (Giller et al., 1997; Lal, 2004; Guo \& Gifford, 2002). In an analysis of forest harvesting studies, Nave et al. (2009) showed that harvesting of native forests reduced soil carbon storage by an average of $8 \%$, with considerably more lost from the forest floor $(30 \%)$ than the mineral soil (no consistent change). In general, forest practices that result in carbon sequestration favour fungi over bacteria (e.g., since fungi have half the respiration rate of bacteria $(30-40 \%$ versus $60 \%)$ ). They should also favour fungal taxa that produce prodigious mycorrhizal networks for increased soil aggregation and connectivity, or that produce decay-resistant compounds. In the interior Douglas-fir forests of British Columbia, forest management practices have generally ignored the importance of ECM fungi or mycorrhizal networks in the natural forest regenerative capacity following disturbance. Over the past century, clearcut or highgrade harvesting along with severe insect attacks and severe fire have taken over mixed fire and insect attacks as the primary disturbance agents in these forests (Campbell et al., 2003; Maclauchlan et al., 2007; Klenner et al., 2008). The standard harvesting practice has been to 
remove the tallest, straightest, largest diameter stems (i.e., the hub trees) for their economic value, and leave patches of smaller residual trees and advance regeneration to grow and disperse seed into the harvested gaps (Vyse et al., 2006). These management practices are characterized by high mortality of establishing seedlings and patchy regeneration $(40 \%$ survival of planted seedlings in the very dry forests; Simard, 2009). High-grading not only compromises mycorrhizal networks and regenerative capacity but probably also affects genotypic diversity of the trees comprising the forests. Indeed, the high-grading management approach, combined with summer drought (Hamann \& Wang, 2006), episodic seed dispersal (Vyse et al., 2006) and gap-phase disturbance regime characteristic of interior Douglas-fir forests (Klenner et al., 2008), has lead to variable natural regeneration success across the dry climatic zones of interior Douglas-fir (Vyse et al., 2006; Stark et al., 2006).

In the moist, warm forests, or at the upper elevations of the dry forests, clearcutting followed by planting has become the most common practice. The interior Douglas-fir nursery stock that is planted on to these sites is grown under high watering and nutrient regimes and thus seedlings are non-mycorrhizal when lifted for planting (Kazantseva et al., 2009). Historically, regeneration of interior Douglas-fir under these conditions has been more or less successful provided site preparation is suitable, frost pockets recognized and weather conditions are favourable. However, the recent increase in extended summer droughts and more variable weather conditions in the wetter forest types, combined with the cumulative high-grading effects and increased severity of natural disturbances (Flannigan et al., 2005; Maclauchlan et al., 2007; Klenner et al., 2008; Kurz et al., 2008a), have changed the structure of these forests and lead to greater uncertainty in regeneration outcomes. Tree mortality is expected to increase even further at species trailing edges as summer drought and disturbance severity increase (Dale et al., 2001; Campbell et al., 2003; Parmesan, 2006). Mycorrhizal colonization and networks should become increasingly important to the recovery of these forests from disturbance as they become increasingly drought-stressed during the summer months as predicted by climate models (Hamann \& Wang, 2006).

Forest practices, therefore, can play an important role in carbon sequestration and forest stability under climate stress. Conservation of whole intact forests should be a global priority given the alarming trends in climate change and loss of biodiversity. Where harvesting is necessary, however, retention of hub trees and their mycorrhizal networks should help maintain the strong carbon storage capacity of forests that is critical to the global carbon balance. Just as conserving living trees plays a critical role in conserving mycorrhizal diversity and function, mycorrhizas in turn play a critical role in the self organization and productivity of forests. By contrast, large-scale clearcutting not only increases greenhouse gas emissions (Kurz et al., 2008b), it also removes critical hub trees, threatens biodiversity (Jones et al., 2003; Martin et al., 2004) and could promote decline of nearby forests.

\subsection{Future management practices}

Forests may shift to new stability domains with climate change (Suding et al., 2004). As discussed in Section 4, climate models predict a dramatic shift in tree species ranges in North America (Parmesan, 2006; Hamann \& Wang, 2006), typically with northward or eastward migration at the leading edges and extensive mortality at the trailing edges. To help mitigate lags in forest re-assembly and minimize the potential for large carbon pulses 
to the atmosphere, humans can play an important role in mitigating the decline of existing forests and in assisting tree migrations (Rehfeldt et al., 2001). At the trailing edges of tree species ranges, conservation of hub trees forming complex mycorrhizal networks should increase ecosystem stability by facilitating natural regeneration. Conserving forests in these warmer ecosystems will be very important for the source of pre-adapted alleles they provide for currently colder climates (Aitken et al., 2008), as well as for their strong carbon storage capacity. At the leading edges, an important potential barrier in tree migration may be in the colonization of non-local tree genotypes by weakly compatible local mycorrhizal fungi. Although most temperate trees are colonized by both host-specific and host-generalist ECM fungi (Molina et al., 1992), thus providing insurance against negative fungal community composition shifts, the symbiosis of specific plant and fungal pairings can range from mutualistic to parasitic (Bever, 2002a; Klironomos, 2003; Jones \& Smith, 2004). Moreover, recent research shows that plants and fungi benefit more frequently with locally adapted associates (Johnson et al., 2010). Indeed, strong feedbacks between compatible symbionts have historically contributed to species coexistence and stability in plant and fungal communities (Bever, 2002b; Klironomos, 2003), whereas weak or antagonistic feedbacks have resulted in forest plantation failures. This research suggests trees that are migrated to new environments may suffer from poor matchings with local mycorrhizal fungi as well as intense competition with existing plants, leading to uncertain performance within local, existing mycorrhizal networks. Such poor marriages could limit the success of assisted tree migrations and contribute to the loss of forest stability (Suding et al., 2004). The loss could be magnified where management practices fail to conserve a diversity of tree and fungal genotypes (Levin, 2005). By contrast, conserving a genetically diverse community of mycorrhizal fungi at the leading edge of tree species ranges may reduce the risk of deleterious matchings and facilitate regeneration of genetically diverse forests with high adaptive capacity (sensu Whitham et al., 2006).

Even with good management and assisted migrations, mature and juvenile tree mortality is expected to increase from disturbances associated with climate change (IPCC, 2007). Mortality can be managed in a manner that eases the transition from one forest type to another, however, by conserving the structural and functional legacies of the original forest and establishing the new forest before the old trees are completely dead. It is well established that healthy plants can transfer nutrients to other healthy plants directly through mycorrhizal networks (Simard \& Durall, 2004; Selosse et al., 2006), but even larger amounts may transfer from dying trees to healthy roots (Simard et al., 2002; Pietikäinen \& Kytöviita, 2007). Where the dying native forest is protected (i.e., not salvage logged) until the new generation or community of trees is established, the new seedlings may be poised to capture nutrients released from the mycorrhizal network of the dying trees before they are acquired by soil microbes. Where new seedlings are not established during the dying process, the organic compounds exuded from senescing roots may be rapidly immobilized by the rhizosphere microbial community and, through turnover, the $\mathrm{CO}_{2}$ respired back to the atmosphere and the inorganic nutrients released to the soil solution for microbial uptake, other plant uptake, or leaching. If germinants of native plants can avoid competition with soil microbes by acquiring carbon and nutrients directly from dying trees through a mycorrhizal network, they may establish more rapidly, thus increasing competiveness with non-networking invasive plants and reducing $\mathrm{CO}_{2}$ feedback to the atmosphere. Mycorrhizal networks connecting new generations with old in forests under climate stress may thus be 
important in conserving existing forests, facilitating native plant establishment and migration, providing barriers to weed invasion, and mitigating large carbon losses.

\section{Conclusions}

Forests have been diminishing world-wide because of land-use changes and are experiencing additional stress from climate change. While $\mathrm{CO}_{2}$ enrichment, warming and nutrient pollution are increasing forest productivity and belowground carbon sequestration in North America and Europe, increases in drought, extreme weather events and deforestation practices are also pushing disturbance regimes outside of their natural range. Wide-spread forest diebacks or decline are already occuring in response to increasing drought, wildfire, and insect and disease attacks with climate change. These have the potential to outweigh any positive effects of climate change factors on increased belowground carbon allocation to mycorrhizas, soil microbes or roots. Recovery of these forests is uncertain given the changing dynamics between climate, trees and their mutualists, as well the changing severity and extent of disturbances. The potential for positive feedbacks from dying forest respiration to atmospheric $\mathrm{CO}_{2}$ levels is high. Humans can play an important role in mitigating forest mortality and assisting migration of species, thus dampening the impacts of climate change.

Mycorrhizas play an important role in the recovery and organization of forests, and it therefore follows that conservation of mycorrhizal fungal communities should help stabilize forests and soils with climate change. Mycorrhizal networks form rapidly following disturbance in the interior Douglas-fir forests of British Columbia, providing critical water and nutrients to establishing seedlings. In mature Douglas-fir forests, most trees, even those of different species, ages and sizes, are connected by a mycorrhizal network. The extensive networks of large hub trees facilitate regeneration of younger trees in the understory, helping them tolerate the stressful environmental conditions. Mycorrhizal networks and hub trees are foundational to the organization of forests because they create favorable local conditions for tree establishment and growth. Therefore, conserving hub trees and mycorrhizal networks appears important to the conservation, regeneration and restoration of forests. Conserving forests, mitigating or managing forest diebacks or declines, and assisting migration of tree species are all important strategies for adapting to the effects of climate change.

\section{References}

Aber, J.D., Neilson, R.F., McNulty, S., Lenihan, J.M., Bachelet, D. \& Drapek, R.J. 2001. Forest processes and global environmental change: predicting the effects of individual and multiple stressors. BioScience 51: 735-751.

Aber, J.D., Goodale, C.L., Ollinger, S.V., Smith, M.-L., Magill, A.H., Martin, M.E., Hallett, R.A. \& Stoddard, J.L. 2003. Is nitrogen deposition altering the nitrogen status of north-eastern forests? BioScience 53: 375-389.

Agerer, R. 2001. Exploration types of ectomycorrhizae: A proposal to classify ectomycorrhizal mycelial systems according to their patterns of differentiation and putative ecological importance. Mycorrhiza 11: 107-114. 
Aitken, S.N., Yeaman, S., Holliday, J., Wang, T. \& Curtis-McLane, S. 2008. Adaptation, migration or extirpation: climate change outcomes for tree populations. Evolutionary Applications 1: 95-111.

Allen, C.D., Macalady, A.K., Chenchouni, H., Bachelet, D., McDowell, N., Vennetier, M., Kitzberger, T., Rigling, A., Breshears, D.D., Hogg, E.H., Gonzalez, P., Fensham, R., Zhang, Z., Castro, J., Demidova, N., Lim, J.-H., Allard, G., Running, S.W., Semerci, A., \& Cobb., N. 2010. A global overview of drought and heat-induced tree mortality reveals emerging climate change risks for forests. Forest Ecology \& Management 259: 660-684.

Allen, M.F., Klironomos, J.N., Treseder, K.K. \& Oechel, W.C. 2005. Responses of soil biota to elevated $\mathrm{CO}_{2}$ in a chaparral ecosystem. Ecological Applications 15: 1701-1711.

Allison, S.D. \& Treseder, K.K. 2008. Warming and drying suppress microbial activity and carbon cycling in boreal forest soils. Global Change Biology 14: 2898-2909.

Allison, S.D., Hanson, C.A. \& Treseder, K.K. 2007. Nitrogen fertilization reduces diversity and alters community structure of active fungi in boreal ecosystems. Soil Biology \& Biochemistry 39: 1878-1887.

Allison, S.D., Czimczik, C.I. \& Treseder, K.K. 2008. Microbial activity and soil respiration under nitrogen addition in Alaskan boreal forest. Global Change Biology 14: 11561168.

Allison, S.D., Wallenstein, M.D. \& Bradford, M.A. 2010. Soil-carbon response to warming dependent on microbial physiology. Nature Geoscience 3: 336-340.

Apps, M. J., Kurz, W.A., Luxmoore, R.J., Nilsson, L.O., Sedjo, R.A., Schmidt, R., Simpson, L.G. \& Vinson, T.S. 2005. Boreal forests and tundra. Water, Air, \& Soil Pollution 70: 39-53.

Arnolds, E. 1991. Decline of ectomycorrhizal fungi in Europe. Agr., Ecos. \& Env. 35: 209-244.

Augé, R.M. 2001. Water relations, drought and vesicular-arbuscular mycorrhizal symbiosis. Mycorrhiza 11: 3-42.

Baleshta K., Simard, S.W., Guy, R.D. \& Chanway, C. 2005. Reducing paper birch density increases Douglas-fir growth and Armillaria root disease incidence. Forest Ecology \& Management 208: 1-13.

Bardgett, R.D., Freeman, C. \& Ostle, N.J. 2008. Microbial contributions to climate change through carbon cycle feedbacks. ISME Journal 2: 805-814.

Barker, J.S. \& Simard, S.W. 2010. Natural regeneration potential of Douglas-fir along wildfire and clearcut severity gradients. In preparation.

Barker, J.S., Simard, S.W., Jones, M.D. \& Durall, D.M. 2010. The influence of wildfire and clear-cutting on ectomycorrhizas of naturally regenerating interior Douglas-fir. In preparation.

Bazazz, F.A. 1990. The response of natural ecosystems to rising global $\mathrm{CO}_{2}$ levels. Annual Review of Ecology and Systematics 21: 167-196.

Beiler, K.J., Durall, D.M., Simard, S.W., Maxwell, S.A. \& Kretzer, A.M. 2010. Mapping the wood-wide web: mycorrhizal networks link multiple Douglas-fir cohorts. New Phytologist 185: 543-553.

Bever, J.D. 2002a. Host-specificity of AM fungal population growth rates can generate feedback on plant growth. Plant \& Soil 244: 281-290.

Bever, J.D. 2002b. Negative feedback within a mutualism: Host-specific growth of mycorrhizal fungi reduces plant benefit. Proc. Royal Soc. London B 269: 2595-2601. 
Bouchard, M., Kneeshaw, D. \& Bergeron, Y. 2008. Ecosystem management based on largescale disturbance pulses: A case study from sub-boreal forests of western Quebec (Canada). Forest Ecology \& Management 256: 1734-1742.

Bradford, M.A., Davies, C.A., Frey, S.D., Maddox, T.R., Melillo, J.M., Mohan, J.E., Reynolds, J.F., Treseder, K.K. \& Wallenstein, M.D. 2008. Thermal adaptation of soil microbial respiration to elevated temperature. Ecology Letters 11: 1316-1327.

Bradley, K.L., Hancock, J.E., Giardina, C.P., Pregitzer, K.S. 2007. Soil microbial community responses to altered lignin biosynthesis in Populus tremuloides vary among three distinct soils. Plant \& Soil 294: 185-201.

Bray, D. 2003. Molecular networks: the top-down view. Science 301: 1864-1865.

Campbell, R., Smith, D.J. \& Arsenault, A. 2003. Multicentury history of western spruce budworm outbreaks in interior Douglas-fir forests. Can. J. For. Res. 36: 1758-1769.

Cardon, Z.G. \& Gage, D.J. 2006. Resource exchange in the rhizosphere: molecular tools and the microbial perspective. Ann. Rev. Ecol., Evol. Syst. 37: 459-488.

Clemmensen, K.E., Michelsen, A., Jonasson, S. \& Shaver, G.R. 2006. Increased ectomycorrhizal fungal abundance after long-term fertilization and warming of two Arctic tundra ecosystems. New Phytologist 171: 391-404.

Cox P.M, Betts R.A, Jones C.D, Spall S.A, Totterdell I.J. 2000 Acceleration of global warming due to carbon-cycle feedbacks in a coupled climate model. Nature 408: 184-187.

Dale, V.H., Joyce, L.A., McNulty, S., Neilson, R.P., Ayres, M.P., Flannigan, M.D., Hanson, P.J., Irland, L.C., Lugo, A.E., Peterson, C.J., Simberloff, D., Swanson, F.J., Stocks, B.J \& Wotton, B.W. 2001. Climate change can affect forests by altering the frequency, intensity, duration, and timing of fire, drought, introduced species, insect and pathogen outbreaks, hurricanes, windstorms, ice storms, or landslides. BioScience 51: 723-734.

Danby, R.K. \& Hik, D.S. 2007. Variability, contingency and rapid change in recent subarctic alpine tree line dynamics. Journal of Ecology 95: 352-363.

Deacon, .JW. \& Donaldson, S.J. 1983. Sequences and interactions of mycorrhizal fungi on birch. Plant \& Soil 71: 257-262.

Dentener, F., Drevet, J., Lamarque, J.F., Bey, I., Eickhout, B., Fiore, A.M., Hauglustaine, D., Horowitz, L.W., Krol, M., Kulshrestha, U.C., Lawrence, M., Galy-Lacaux, C., Rast, S., Shindell, D., Stevenson, D., Van Noije, T., Atherton, C., Bell, N., Bergman, D., Butler, T., Cofala, J., Collins, B., Doherty, R., Ellingsen, K., Galloway, J., Gauss, M., Montanaro, V., Müller, J.F., Pitari, G., Rodriguez, J., Sanderson, M., Solmon, F., Strahan, S., Schultz, M., Sudo, K., Szopa, S. \& Wild, O. 2006. Nitrogen and sulfur deposition on regional and global scales: A multimodel evaluation. Global Biogeochemical Cycles 20:

Deslippe, J.R. \& Simard, S.W. 2010. Carbon transfer through mycorrhizal networks may facilitate shrub expansion in Low-Arctic tundra. Ecology Letters, submitted.

Deslippe, J.R., Haartman, M., Mohn, W.W. \& Simard, S.W. 2010. Long-term experimental manipulation of climate alters the ectomycorrhizal community of Betula nana in Arctic tundra. Global Change Biology, in press.

Drigo, B., Kowalchuk, G.A. \& van Veen, J.A. 2008. Climate change goes underground: effects of elevated atmospheric $\mathrm{CO}_{2}$ on microbial community structure and activities in the rhizosphere Biology \& Fertility of Soils 44: 667-679. 
Durall, D.M., Gamiet, S., Simard, S.W., Kudrna, L. \& Sakakibara, S.M. 2006. Effects of clearcutting and tree species composition on the diversity and community composition of epigeous fruit bodies formed by ectomycorrhizal fungi. Can. J. Bot. 84: 966-980.

FAO. 2006. Global forest resources assessment 2005. FAO Forestry Paper 147, Rome.

Flannigan, M.D., Logan, K.A., Amiro, B.D., Skinner, W.R. \& Stocks, B.J. 2005. Future area burned in Canada. Climate Change 72: 1-16.

Giller, K.E., Beare, M.H., Lavelle, P., Izac, -M.N. \& Swift, M.J. 1997. Agricultural intensification, soil biodiversity and agroecosystem function. Applied Soil Ecology 6: 3-16.

Guo, L.B. \& Gifford, R.M. 2002. Soil carbon stocks and land use change: a meta analysis. Global Change Biology 8: 345-360.

Hagerman, S.M., Sakakibara, S.M. \& Durall, D.M. 2001. The potential for woody understory plants to provide refuge for ectomycorrhizal inoculum at an interior Douglas-fir forest after clear-cut logging. Can. J. For. Res. 31: 711-721.

Hamann, A. \& Wang, T. 2006. Potential effects of climate change on ecosystem and tree species distribution in British Columbia. Ecology 87: 2773-2786.

Hansen, C.A., Allison, S.D., Bradford, M.A., Wallenstein, M.D. \& Treseder, K.K. 2008. Fungal taxa target different carbon sources in forest soil. Ecosystems 11: 1157-1167.

Heineman, J.E., Sachs, D.L., Mather, W.J. \& Simard, S.W. 2010. Investigating the influence of climate, site, location and treatment factors on damage to young lodgepole pine in British Columbia. Can. J. For.Res. 40: 1109-1127.

Hobbie, E.A. 2006. Carbon allocation to ectomycorrhizal fungi correlates with belowground allocation in culture studies. Ecology 87: 563-569.

Hobbie, E.A. \& Agerer, R. 2010. Nitrogen isotopes in ectomycorrhizal sporocarps correspond to belowground exploration types. Plant \& Soil 327: 71-83.

Hobbie, J.E. \& Hobbie, E.A. $2006{ }^{15} \mathrm{~N}$ in symbiotic fungi and plants estimates nitrogen and carbon flux rates in Arctic. Ecology 87: 816-822.

Hobbie, S.E. 2000.Interactions between litter lignin and soil nitrogen availability during leaf litter decomposition in a Hawaiian montane forest. Ecosystems 3: 484-494.

Hoeksema, J.D. \& Forde, S. E. 2008. A meta-analysis of factors affecting local adaptation between interacting species. Americal Naturalist 171: 275-290.

Högberg, P. \& Högberg, M.N. 2002. Extramatrical ectomycorrhizal mycelium contributes one-third of microbial biomass and produces, together with associated roots, half of the dissolved organic carbon in a forest soil. New Phytologist 154: 791-795.

Högberg, P., Högberg, M.N., Göttlicher, S.G., Berson, N.R., Keel, S.G., Metcalfe, D.B., Campbell, C., Schindlbacher, A., Hurry, V., Lundmark, T., Linder, S. \& Näsholm, T. 2007. High temporal resolution tracing of photosynthate carbon from tree canopy to forest soil microorganisms. New Phytologist 177: 220-228.

Hogg, E.H., Brandt, J.P. \& Krochtubajda, R. 2002. Growth and dieback of aspen forests in northwestern Alberta in relation to climate and insects. Can. J. For. Res. 32: 823832.

Houghton, R.A., Skole, D.L., Nobre, C.A., Hackler, J.L., Lawrence, K.T. \& Chomentowski, W.H. 2000. Annual fluxes of carbon from deforestation and regrowth in the Brazilian Amazon. Nature 403: 301-304. 
IPCC. 2007. Climate Change 2007: Synthesis Report. Contribution of Working Groups I, II and III to the Fourth Assessment Report of the Intergovernmental Panel on Climate Change [Core Writing Team, Pachauri, R.K. \& Reisinger, A. (eds.)]. IPCC, Geneva, Switzerland, $104 \mathrm{pp}$.

Janssens, I.A., Dieleman, W., Luyssaert, S., subke, J.A., Reichstein, M., Ceulemans, R., Ciais, P., Dolman, A., Grace, J., Matteucci, G., Papale, D., Piao, S.I., schulze, E.D., Tang, J., \& Law, B.E. 2010. Reduction of forest soil respiration in response to nitrogen deposition. Nature GeoScience 3: 315-322.

Jerabkova, L., Prescott, C.E. \& Kishchuk, B.E. 2006. Nitrogen availability in soil and forest floor of contrasting types of boreal mixedwood forests. Can. J. For. Res. 36: 112-122.

Johnson, D., Leake, J.R., Ostle, N., Ineson, P. \& Read, D.J. 2002. In situ ${ }^{13} \mathrm{CO}_{2}$ pulse-labelling of upland grassland demonstrates a rapid pathway of carbon flux from arbuscular mycorrhizal mycelia to the soil. New Phytologist 153: 327-334.

Johnson, N.C., Wolf, J., Reyes, M.A., Panter, A., Koch, G.W. \& Redman, A. 2005. Species of plants and associated arbuscular mycorrhizal fungi mediate mycorrhizal responses to $\mathrm{CO}_{2}$ enrichment. Global Change Biology 11: 1156-1166.

Johnson, N.C., Wilson, G.W.T., Bowker, M.A., Wilson, J.A. \& Miller, R.M. 2010. Resource limitation is a driver of local adaptation in mycorrhizal symbioses. PNAS 107: 2093-2098.

Johnstone, J.F. \& Chapin, F.S. 2003. Non-equilibrium succession dynamics indicate continued northern migration of lodgepole pine. Global Change Biology 9: 14011409.

Jones, C., McConnell, C., Coleman, K., Cox, P., Falloon, P., Jenkinson, D. \& Powlson, D. 2004. Global climate change and soil carbon stocks; predictions from two contrasting models for the turnover of organic carbon in soil. Global Change Biology 11: 154166.

Jones, M.D. \& Smith, S.E. 2004. Exploring functional definitions of mycorrhizas: Are mycorrhizas always mutualisms? Botany 82: 1089-1109.

Jones, M.D., Durall, D.M., Harniman, S.M.K., Classen, D.C. \& Simard, S.W. 1997. Ectomycorrhizal diversity on Betula papyrifera and Pseudotsuga menziesii seedlings grown in the greenhouse or outplanted in single-species and mixed plots in southern British Columbia. Can. J. For. Res. 27: 1872-1889.

Jones, M.D., Durall, D.M. \& Cairney, J.W.G. 2003. Ectomycorrhizal fungal communities in young forest stands regenerating after clearcut logging. New Phytologist 157: 399422 .

Jones MD, Ward V, Twieg BD, Durall DM, \& Simard SW. 2010. Functional diversity and redundancy for extracellular enzyme activity of Douglas-fir ectomycorrhizas after wildfire or clearcut logging. Functional Ecology, in press.

Kazantseva, O., Bingham, M.A., Simard, S.W. \& Berch, S.M. 2009. Effects of growth medium, nutrients, water and aeration on mycorrhization and biomass allocation of greenhouse-grown interior Douglas-fir seedlings. Mycorrhiza 20: 51-66.

Keeling, C.D. 1998. Rewards and penalties of monitoring the Earth. Annual Review of Energy and the Environment 23: 25-82.

Kiers, E.T. \& van der Heijden, M.A. 2006. Mutualistic stability in the arbuscular mycorrhizal symbiosis: exploring hypotheses of evolutionary cooperation. Ecology 87: 16271636. 
Klenner, W., Walton, R., Arsenault, A. \& Kramseter, L. 2008. Dry forests in the southern interior of British Columbia: historic disturbances and implications for restoration and management. Forest Ecology \& Management 206: 1711-1722.

Kliejunas, J.T., Geils, B.W., Glaeser, J.M., Goheen, E.M., Hennon, P., Kim, M.-S., Kope, H., Stone, J., Sturrock, R. \& Frankel, S.J. 2009. Review of literature on climate change and forest diseases of western North America. Gen. Tech. Rep., PSW-GTR-225. Albany, CA: U.S. Department of Agriculture, Forest Service, Pacific Southwest Research Station. 54 p.

Klironomos, J.N. 2003. Variation in plant response to native and exotic mycorrhizal fungi. Ecology 84: 2292-2301.

Klironomos, J.N., Allen, M.F., Rillig, M.C., Piotrowski, J., Makvandi-Nejad, S., Wolfe, B.E. \& Powell, J.R. 2005. Abrupt rise in atmospheric $\mathrm{CO}_{2}$ overestimates community response in a model plant-soil system. Nature 433: 621-624.

Kurz, W.A. \& Apps, M.J. 1999. A 70-year retrospective analysis of carbon fluxes in the Canadian forest sector. Ecological Applications 9: 526-547.

Kurz, W.A., Stinson, G. \& Rampley, G.J. 2008a. Could increased boreal forest ecosystem productivity offset carbon losses from increased disturbances? Phil. Trans. R. Soc. B 363: 2259-2268.

Kurz, W.A., Dymond, C.C., Stinson, G., Rampley, G.J., Neilson, E.T., Carroll, A.L., Ebata, T. \& Safranyik, L. 2008b. Mountain pine beetle and forest carbon feedback to climate change. Nature 452: 987-990.

Kurz, W.A., Stinson, G., Rampley, G.J., Dymond, C.C. \& Neilson, E.T. 2008c. Risk of natural disturbances makes future contribution of Canada's forests to the global carbon cycle highly uncertain. PNAS 105: 1551-1555.

Lal, R. 2004. Soil carbon sequestration impacts on global climate change and food security. Science 304, 1623-1627.

Lerat, S., Gauci, R., Catford, J.G., Vierheilig, H., Piché, Y. \& Lapointe, L. 2002. ${ }^{14} \mathrm{C}$ transfer between the spring ephemeral Erythronium americanum and sugar maple saplings via arbuscular mycorrhizal fungi in natural stands. Oecologia 132: 181-187.

Levin, S.A. 2005. Self-organization and the emergence of complexity in ecological systems. BioScience 55: 1075-1079.

Lilleskov, E.A., Fahey, T.J. \& Lovett, G.M. 2001. Ectomycorrhizal fungal aboveground community change over a nitrogen deposition gradient. Ecological Applications 11: 397-410.

Lilleskov, E.A., Fahey, T.J., Horton, T.R. \& Lovett, G.M. 2002. Belowground ectomycorrhizal fungal community change over a nitrogen deposition gradient in Alaska. Ecology 83: 104-115

Liu, Y., Stanturf, J. \& Goodrick, S. 2010. Trends in global wildfire potential in a changing climate. Forest Ecology \& Management 259: 685-697.

Lovelock, J. 2009. The vanishing face of Gaia. Basic Books, New York.

Maclauchlan, L., Cleary, M., Rankin, L., Stock, A. \& Buxton, K. 2007. 2007 Overview of Forest Health in the Southern Interior Forest Region. BC Min. For., Kamloops, Canada.

McLachlan, J.S. \& Clark, J.S. 2004. Reconstructing historical ranges with fossil data at continental scales. Forest Ecology \& Management 197: 139-147. 
Malcolm, J.R., Liu, C., Neilson, R.P., Hansen, L. \& Hannah, L. 2006. Global warming and extinctions of endemic species from biodiversity hotspots. Conservation Biology, 20: 538-548.

Martin, K., Aitken, K.E.H. \& Wiebe, K.L. 2004. Nest sites and nest webs for cavity-nesting communities in interior British Columbia, Canada: nest characteristics and niche partitioning. The Condor 106: 5-19.

McGuire, K.L. 2007. Common ectomycorrhizal networks may maintain monodominance in a tropical rain forest. Ecology 88: 567-574.

Miller, R.M., Jastrow, J.D. \& Reinhardt, D.R. 1995. External hyphal production of vesiculararbuscular mycorrhizal fungi in pasture and tallgrass prairie. Oecologia 103: 17-23.

Miller, R.M., Miller, S.P., Jastrow, J.D. \& Rivetta, C.B. 2002. Mycorrhizal mediated feedbacks influence net carbon gain \& nutrient uptake in Andropogon gerardii. New Phytologist 155:149-162.

Molina, R., Massicotte, H. \& Trappe, J.M. 1992. Specificity phenomenon in mycorrhizal symbiosis: community-ecological consequences and practical implications. Page 357-423 in Allen, M.F., ed. Mycorrhizal Functioning: An Integrative Plant-Fungal Process. Chapman Hall, New York, NY, USA.

Morrison, D.J., Wallis, G.W. \& Weir, L.C. 1988. Control of Armillaria and Phellinus root diseases: 20-year results from the Skimikin stump removal experiment. Can. For. Serv., Pac. For. Cen., Victoria, B.C. Inf. Rep. BC-X-302.

Mueller, R.C., Scudder, C.M., Porter, M.E., Trotter III, R.T., Gehring, C.A. \& Whitham, T.G. 2005. Differential tree mortality in response to severe drought: evidence for longterm vegetation shifts. Journal of Ecology 93: 1085-1093.

Näsholm, T., Ekblad, A., Nordin, A., Giesler, R, Högberg, M. \& Högberg, P.1998. Boreal forest plants take up organic nitrogen. Nature 392: 914-916.

Nara, K. and Hogetsu, T. 2004. Ectomycorrhizal fungi on established shrubs facilitate subsequent seedling establishment of successional plant species. Ecology 85: 17001707.

Nave, L.E., Vance, E.D., Swanston, C.W., \& Curtis, P.S. 2010. Harvest impacts on soil carbon storage in temperate forests. Forest Ecology \& Management 259: 857-866.

Norby, R.J., Cotrufo, M.F., Ineson, P., O'Neill, E.G., Canadell, J.G. 2001.Elevated CO2, litter chemistry, and decomposition: a synthesis. Oecologia 127:153-165.

Oliver, C. \& Larson, B.C. 1997. Forest stand dynamics: updated edition. Wiley, New York.

Parmesan, C. 2006. Ecological and evolutionary responses to recent climate change. Annual Rev. Ecol. Evol. Syst. 37: 637-669.

Parrent, J.L. \& Vilgalys, R. 2007. Biomass and compositional responses of ectomycorrhizal fungal hyphae to elevated $\mathrm{CO}_{2}$ and nitrogen fertilization. New Phytologist 176: $164-174$.

Pendall, E., Bridgham, S., Hanson, P.J., Hungate, B., Klicklighter, D.W., Johnson, D.W., Law, B.E., Luo, Y., Megonigal, J.P., Olsrud, M., Ryan, M.G. \& Wan, S. 2004. Belowground process responses to elevated $\mathrm{CO}_{2}$ and temperature: A discussion of observations, measurement methods, and models. New Phytologist 162: 311-322.

Pendall, E., Rustad, L. \& Schimel, J. 2008. Toward a predictive understanding of belowground process responses to climate change: have we moved any closer? Functional Ecology 22: 937-940. 
Peter, M., Ayer F. \& Egli, S. 2001. Nitrogen addition in a Norway spruce stand altered macromycete sporocarp production and below-ground ectomycorrhizal species composition. New Phytologist 149: 311-325.

Petit, R.J., Aguinagalde, I., de Beaulieu, L., Bittkau, C., Brewer, S., Cheddadi, R., Ennos, R., Fineschi, S., Grivet, D., Lascoux, M., Mohanty, A., Müller-Starck, G., DemesureMusch, B., Palmé, A., Martin, J.P., Rendell, S. \& Vendramin, G.G. 2003. Glacial refugia: hotspots but not melting pots of genetic diversity. Science 300: 1563-1565.

Pietikäinen, A. \& Kytöviita, M.-M. 2007. Defoliation changes mycorrhizal benefit and competitive interactions between seedlings and adult plants. Journal of Ecology 95: 639-647.

Philip, L.J. 2006. Carbon transfer between ectomycorrhizal paper birch (Betula papyrifera) and Douglas-fir (Pseudotsuga menziesii). PhD thesis, UBC, Vancouver, Canada.

Philip, L.J., Simard, S.W. \& Jones, M.D. 2010. Pathways for belowground carbon transfer between paper birch and Douglas-fir seedlings. Plant Ecology \& Diversity, in press.

Poorter, H. 1993. Interspecific variation in the growth response of plants to an elevated ambient CO2 concentration. Vegetatio 104/105: 77-97.

Pritchard, E. T. G., Strand, A.E., McCormack, M.A., Davis, M.A., Finzi, A.C., Jackson, R.B., Roser, M., Rogers, H.H. \& Oren, R. 2008. Fine root dynamics in a loblolly pine forest are influenced by free-air-CO2- enrichment: a six-year-minirhizotron study. Global Change Biology 14: 1-15.

Read D. J. \& Perez-Moreno, J. 2003. Mycorrhizas and nutrient cycling in ecosystems - a journey towards relevance? New Phytologist 157: 475-492.

Rehfeldt, G.E., Wykoff, W.R. \& Ying, C.C. 2001. Physiological plasticity, evolution and impacts of a changing climate on Pinus contorta. Climatic Change 50: 355-37.

Rice, C.W., White, P.M., Fabrizzi, K.P. \& Wilson, G.W.T. 2004. Managing the microbial community for soil carbon management. Supersoil 2004: 3rd Australian New Zealand Soils Conference 5-9 December 2004, University of Sydney, Australia.

Rillig, M.C., Wright, S.F., Nichols, K.A., Schmidt, W.F. \& Torn, M.S. 2001. Large contribution of arbuscular mycorrhizas to soil C pools in tropical forest soils. Plant \& Soil 233: 167-177.

Rogers, H.H., Runion, G.B., Krupa, S.V. 1994. Plant responses to atmospheric $\mathrm{CO}_{2}$ enrichment with emphasis on roots and the rhizosphere. Environmental Pollution 83: 155-189.

Rustad, L.E., Campbell, J.L., Marion, G.M., Norby, R.J., Mitchell, M.J., Hartley, A.E., Cornelissen, J.H.C. \& Gurevitch, J. 2001. A meta-analysis of the response of soil respiration, net nitrogen mineralization, and aboveground plant growth to experimental ecosystem warming. Oecologia 126: 542-562.

Rygiewicz, P.T. \& Anderson, C.P. 1994. Mycorrhizae alter quality and quantity of carbon allocated below ground. Nature 369: 58-60.

Schlesinger, W.H. \& Andrews, J.A. 2004. Soil respiration and the global carbon cycle. Biogeochemistry 48: 7-20.

Schoonmaker, A.L., Teste, F.P., Simard, S.W. \& Guy, R.D. 2007. Tree proximity, soil pathways and common mycorrhizal networks: their influence on utilization of redistributed water by understory seedlings. Oecologia 154: 455-466. 
Schuur, E.A.G., Vogel, J.G., Crummer, K.G., Lee, H., Sickman, J.O. \& Osterkamp, T.E. 2009. The effect of permafrost thaw on old carbon release and net carbon exchange from tundra. Nature 459: 556-559.

Sedjo, R. 1993. The carbon cycle \& global forest ecosystem. Water, Air, Soil Poll. 70: 295-307

Selosse, M.-A., Richard, F., He, X. \& Simard, S.W. 2006. Mycorrhizal networks: les liaisons dangeureuses? Trends in Ecology \& Evolution 21: 621-628.

Simard, S.W. 2009. The foundational role of mycorrhizal networks in the self-organization if interior Douglas-fir forests. Forest Ecology \& Management 258S: S95-S107.

Simard, S.W. \& Durall, D.M. 2004. Mycorrhizal networks: a review of their extent, function, and importance. Botany 82: 1140-1165.

Simard, S.W., Perry, D.A., Jones, M.D., Myrold, D.D., Durall, D.M. \& Molina, R. 1997a. Net transfer of carbon between ectomycorrhizal tree species in the field. Nature 388: 579-582.

Simard, S.W., Perry, D.A., Smith, J.W. \& Molina, R. 1997b. Effects of soil trenching on occurrence of ectomycorrhizae on Psuedostuga menziesii seedlings grown in mature forests of Betula papyrifera and Psuedotsuga menziesii. New Phytologist 136: 327-340.

Simard, S.W., Jones, M.D. \& Durall DM. 2002. Carbon and nutrient fluxes within and between mycorrhizal plants. Pages 33-61 in M. van der Heijden and I. Sanders, eds. Mycorrhizal Ecology. Springer-Verlag, Heidelberg. Ecological Studies, Vol. 157.

Simard, S.W., Hagerman, S.M., Sachs, D.L., Heineman, J.L. \& Mather, W.J. 2005. Conifer growth, Armillaria ostoyae root disease and plant diversity responses to broadleaf competition reduction in temperate mixed forests of BC. Can. J. For. Res. 35: 843859.

Smith, S.E. \& Read, D.J. 1997. Mycorrhizal symbiosis, 2nd ed. Academic Press, London, UK.

Southworth, D., He, X.-H., Swenson, W. \& Bledsoe, C.S. 2005. Application of network theory to potential mycorrhizal networks. Mycorrhiza 15: 589-595.

Spittlehouse, D.L. 2008. Climate change, impacts, and adaptation secenarios: climate change and forest and range management in British Columbia. B.C. Min. For. Range, Res. Br., Victoria, BC. Tech. Rep. 045.

Staddon, P.L., \& Fitter, A.H. 1998. Does elevated atmospheric carbon dioxide affect arbuscular mycorrhizas? Trends in Ecology \& Evolution 13: 455-458.

Staddon, P.L., Fitter, A.H. \& Robinson, D. 1999. Effects of mycorrhizal colonization and elevated atmospheric carbon dioxide on carbon fixation and below-ground carbon partitioning in Plantago lanceolata. Journal of Experimental Botany 335: 853-860.

Stark, K.E., Arsenault, A. \& Bradfield, G.E. 2006. Soil seed banks and plant community assembly following disturbance by fire and logging in the interior Douglas-fir forests of south-central British Columbia. Botany 84: 1548-1560.

Suding, K.N., Gross, K.L. \& Houseman, G.R. 2004. Alternative states and positive feedbacks in restoration ecology. Trends in Ecology \& Evolution 19: 46-53.

Talbot, J.M., Allison, S.D. \& Treseder, K.K. 2008. Decomposers in disguise: mycorrhizal fungi as regulators of soil carbon dynamics in ecosystems under global change. Functional Ecology 22: 955-963.

Teste, F.P. \& Simard, S.W. 2008. Mycorrhizal networks and distance from mature trees alter patterns of competition and facilitation in dry Douglas-fir forests. Oecologia 158: 193-203. 
Teste, F.P., Simard, S.W. \& Durall, D.M. 2009a. Role of mycorrhizal networks and tree proximity in ectomycorrhizal colonization of planted seedlings. Fungal Ecology 2: 21-30.

Teste, F.P., Simard, S.W., Durall, D.M., Guy, R.D., Jones, M.D. \& Schoonmaker, A.L. 2009b. Access to mycorrhizal networks and tree roots: importance for seedling survival and resource transfer. Ecology 90: 2808-2822.

Teste FP, Simard SW, Durall DM, Guy RD, \& Berch SM. 2010. Net carbon transfer under soil disturbance between Pseudostuga menziesii seedlings in the field. Journal of Ecology 98:429-439.

Thomas, C.D., Cameron, A., Green, R.E. Bakkenes, M., Beaumont, L.J., Collingham, Y.C., Erasmus, B.F.N., de Siqueira, M.F., Grainger, A., Hannah, L., Hughes, L., Huntley, B., van Jaarsveld, A.S., Midgley, G.F., Miles, L., Ortega-Huerta, M.A., Peterson, A.T., Philips, O.L. \& Williams, S.E. 2004. Extinction risk from climate change. Nature 427: 145-148.

Thomas, R.Q., Canham, C.D., Weathers, K.C. \& Goodale, C.L. 2010. Increased tree carbon storage in response to nitrogen deposition in the US. Nature Geoscience 3: 13-17.

Treseder, K.K. 2004. A meta-analysis of mycorrhizal responses to nitrogen, phosphorus, and atmospheric $\mathrm{CO}_{2}$ in field studies. New Phytologist 164: 347-355.

Treseder, K.K. 2005. Nutrient acquisition strategies of fungi and their relation to elevated atmospheric $\mathrm{CO}_{2}$. In: The Fungal Community: Its Organization and Role in the Ecosystem, Third Edition. Edited by: J. Dighton, J.F. White \& P. Oudemans. Taylor \& Francis Group, LLC. ISBN: 978-1-4200-2789-1. Chapter 26, pp 713-731.

Treseder, K.K \& Turner, K. 2007. Glomalin in ecosystems. Soil Sci. Soc. Am. J. 71: 1257-1266.

Treseder, K.K. 2008. Nitrogen additions and microbial biomass: a meta-analysis of ecosystem studies. Ecology Letters 11: 1111-1120.

Treseder, K.K., Egerton-Warburton, L.M., Allen, M.F., Cheng, Y. \& Oechel, W.C. 2003. Alteration of soil carbon pools and communities of mycorrhizal fungi in chaparral exposed to elevated carbon dioxide. Ecosystems 6: 786-796.

Treseder, K.K., Czimczik, C.I., Trumbore, S.E. \& Allison, S.D. 2008. Uptake of an amino acid by ectomycorrhizal fungi in a boreal forest. Soil Biology \& Biochemistry 40: 19641966.

Tu, C., Booker, F.L., Watson, D.M., Chen, X., Rufty, T.W., Shi, W. \& Hu, S.J. 2006. Mycorrhizal mediation of plant $\mathrm{N}$ acquisition and residue decomposition: impact of mineral N inputs. Global Change Biology 12, 793-803.

Twieg, B., Durall, D.M. \& Simard, S.W. 2007. Ectomycorrhizal fungal succession in mixed temperate forests. New Phytologist 176: 437-447.

Twieg, B, Durall DM, Simard SW, Jones MD. 2009. Influence of stand age and soil properties on ectomycorrhizal communities in mixed temperate forests. Mycorrhiza 19: 305316.

Van der Heijden, M.G.A. \& Horton, T.R. 2009. Socialism in soil? The importance of mycorrhizal fungal networks for facilitation in natural ecosystems. Journal of Ecology 97, 1139-1150.

Vitousek, P.M. 1994. Beyond global warming: ecology and global change. Ecology 75: 18611876. 
Vitousek, P.M., Aber, J.D., Howarth, R.W., Likens, G.E., Matson, P.A., Schindler, D.W., Schlesinger, W.H. \& Tilman, D.G. 1997. Human alteration of the global nitrogen cycle: sources and consequences. Ecological Applications 7: 737-750.

Vyse, A., Ferguson. C., Simard, S.W., Kano, T. \& Puttonen, P. 2006. Growth of Douglas-fir, lodgepole pine, and ponderosa pine underplanted in a partially-cut, dry Douglasfir stand in south central British Columbia. Forestry Chronicle 82: 723-732.

Whitham, T.G., Bailey, J.K., Schweitzer, J.A., Shuster, S.M., Bangert, R.K., LeRoy, C.J., Lonsdorf, E.V., Allan, G.J., DiFazio, S.P., Potts, P.M., Fischer, D.G., Gehring, K.A., Lindroth, R.L., Marks, J.C., Hart, S.C., Wimp, G.M. \& Wooley, S.C. 2006. A framework for community and ecosystem genetics: from genes to ecosystems. Nature Review Genetics 7: 510-523.

Zak, D.R., Pregitzer, K.S., Curtis, P.S., Vogel, C.S., Holmes, W.E. \& Lussenhop, J. 2000. Atmospheric $\mathrm{CO}_{2}$, soil-N availability, and allocation of biomass and nitrogen by Populus tremuloides. Ecological Applications 10: 34-46.

Zhu, Y.-G. \& Miller, R.M. 2004. Carbon cycling by arbuscular mycorrhizal fungi in soil-plant systems. Trends in Plant Science 8: 407-409. 


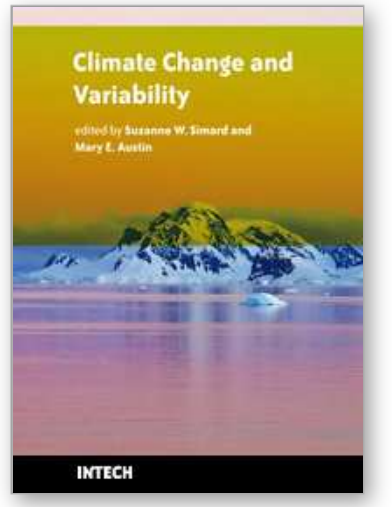

\author{
Climate Change and Variability \\ Edited by Suzanne Simard
}

ISBN 978-953-307-144-2

Hard cover, 486 pages

Publisher Sciyo

Published online 17, August, 2010

Published in print edition August, 2010

Climate change is emerging as one of the most important issues of our time, with the potential to cause profound cascading effects on ecosystems and society. However, these effects are poorly understood and our projections for climate change trends and effects have thus far proven to be inaccurate. In this collection of 24 chapters, we present a cross-section of some of the most challenging issues related to oceans, lakes, forests, and agricultural systems under a changing climate. The authors present evidence for changes and variability in climatic and atmospheric conditions, investigate some the impacts that climate change is having on the Earth's ecological and social systems, and provide novel ideas, advances and applications for mitigation and adaptation of our socio-ecological systems to climate change. Difficult questions are asked. What have been some of the impacts of climate change on our natural and managed ecosystems? How do we manage for resilient socio-ecological systems? How do we predict the future? What are relevant climatic change and management scenarios? How can we shape management regimes to increase our adaptive capacity to climate change? These themes are visited across broad spatial and temporal scales, touch on important and relevant ecological patterns and processes, and represent broad geographic regions, from the tropics, to temperate and boreal regions, to the Arctic.

\title{
How to reference
}

In order to correctly reference this scholarly work, feel free to copy and paste the following:

Suzanne Simard, and Mary Austin (2010). The Role of Mycorrhizas in Forest Soil Stability with Climate Change, Climate Change and Variability, Suzanne Simard (Ed.), ISBN: 978-953-307-144-2, InTech, Available from: http://www.intechopen.com/books/climate-change-and-variability/the-role-of-mycorrhizas-in-forest-soilstability-with-climate-change

\section{INTECH}

open science | open minds

\author{
InTech Europe \\ University Campus STeP Ri \\ Slavka Krautzeka 83/A \\ 51000 Rijeka, Croatia \\ Phone: +385 (51) 770447 \\ Fax: +385 (51) 686166 \\ www.intechopen.com
}

\author{
InTech China \\ Unit 405, Office Block, Hotel Equatorial Shanghai \\ No.65, Yan An Road (West), Shanghai, 200040, China \\ 中国上海市延安西路65号上海国际贵都大饭店办公楼 405 单元 \\ Phone: +86-21-62489820 \\ Fax: +86-21-62489821
}


(C) 2010 The Author(s). Licensee IntechOpen. This chapter is distributed under the terms of the Creative Commons Attribution-NonCommercialShareAlike-3.0 License, which permits use, distribution and reproduction for non-commercial purposes, provided the original is properly cited and derivative works building on this content are distributed under the same license. 